\title{
Epoxide Hydrolase 1
}

National Cancer Institute

\section{Source}

National Cancer Institute. Epoxide Hydrolase 1. NCI Thesaurus. Code C16860.

Epoxide hydrolase 1 ( $455 \mathrm{aa}, \sim 53 \mathrm{kDa}$ ) is encoded by the human EPHX1 gene. This protein is involved in the hydrolysis of cyclic organic compounds. 